\title{
The auditing profession - a lifelong challenge for Balkan's students
}

\author{
Anita Milanova ${ }^{1}$, Dusica Manceva ${ }^{2}$, Janka Dimitrova ${ }^{3}$ \\ 1"' Goce Delcev" University - Faculty of Economics - Stip, Republic of Macedonia, \\ anita.083388@ugd.edu.mk \\ ${ }^{2 " G o c e ~ D e l c e v " ~ U n i v e r s i t y ~-~ F a c u l t y ~ o f ~ E c o n o m i c s ~-~ S t i p, ~ R e p u b l i c ~ o f ~ M a c e d o n i a, ~}$ \\ dusica.083365@ugd.edu.mk \\ ${ }^{3}$ Goce Delcev" University - Faculty of Economics - Stip, Republic of Macedonia, \\ janka.dimitrova@ugd.edu.mk
}

\begin{abstract}
Auditing, understood as a method of examination, aims to help in the responsibility and control in conducting the economic and financial activities in the company. It (above all, its independent opinion) assures users of financial statement information that their decisions or actions will not be taken on the basis of unknown and unaudited business financial events.

Having in mind the huge role of the audit to raise the credibility of the financial statements, the subject and goal of research in this paper will be the development and functioning of the audit profession in some Balkan countries (Macedonia, Serbia, Montenegro, Bosnia and Herzegovina and Slovenia).

In addition, a research will be presented on the necessary qualifications (education) for taking the exam for certified auditor, body conducting the exam, body issuing the license, number of exams, price, number of registered auditors and audit companies. Additionally, a survey conducted among students from the faculties of economics in the Balkan countries (Macedonia, Serbia, Montenegro, Bosnia and Herzegovina and Slovenia) will be presented to find out the level of students' familiarity with the functioning of the auditing profession and the interest for auditing to be their life calling.
\end{abstract}

Key words: audit, certified auditor, student, institute of certified auditors

\section{Introduction}

The audit covers a wide range of knowledge in the areas of accounting, economics, law, ethical and legal norms, mathematical and statistical methods, and is a conglomeration of disciplines and techniques that enable a certified auditor to make judgments about the veracity and reliability of financial reports to the audited entity. An audit is a set of theories and concepts applied to examine the various business cycles of an entity, such as the revenue cycle, sales, procurement, production, and the examination of assets, resources, and capital. "The audit 
includes examination and evaluation of the operation, organization and business functions, the manner of making business decisions, the functioning of the information system of the audited entities, as well as other issues relevant to their operation" [1].

Auditing, understood as a method of examination, aims to help in the responsibility and control in the economic and financial activities in the company. It, and its independent opinion, assures the users of the information from the financial statements that their decisions or actions will not be taken on the basis of unknown and unaudited business financial events. Given the main purpose of the audit which increases the company's accountability and its economic efficiency, its role can be observed as [2]: social, economic, psychological and public or as a personal interest.

In the early 1990s, major socio-economic changes took place in the former Yugoslavia. In this period was a transition to a market economy, a transition from a socially to a private property or a popularly called privatization process. The ownership restructuring of enterprises, banks and other business entities, the influx of foreign investments in the country, the establishment and development of stock exchanges and other reform processes have imposed the need to introduce auditing as an independent profession, which is necessary for the development of financial market, the market for goods and services and economic stability in general.

The changes in the accounting system, and thus the audit, did not adequately follow this transition, so that it was manifested by presenting financial statements that did not reflect the real situation of assets, sources, revenues and expenditures and the achieved financial result. As a result, there were various forms of financial indiscipline which manifested itself through the gray economy, misappropriation of property (overflow of capital), improper settlement of liabilities to the state and creditors, financial insolvency, declining production, the emergence of large companies losers, decline of the living standard of the population, which slowed down the process of inclusion of the Macedonian economy in the world economic trends.

The audit was practiced within the former SFRY through the Social Accounting Service, but due to the chosen way of institutionalization and implementation in practice it did not give the desired results and could not be called an independent audit profession. In conditions when according to the law the annual financial statements were to be audited, and there were no certified auditors, the institution of certified auditor with temporary authorization was introduced, and then to start with professional education and taking the exam for obtaining the title of certified auditors with a certificate.

The initial steps towards improving the quality of the presented financial statements were made by adopting a legal framework for auditing and by adopting the international auditing standards and the Code of Ethics of IFAK professional accountants. This created conditions and basis for the development of the auditing profession that enjoys a great reputation in the modern developed world.

\section{Comparative analysis of the functioning of the audit profession in the Balkan countries}

Depending on the conditions in which the audit took place, the ways in which it is implemented and the guidelines for its improvement in some of the Balkan countries (Macedonia, Serbia, Montenegro, Bosnia and Herzegovina and Slovenia), a comparative analysis was made where as key elements for perceiving the differences and the similarities are taken, the necessary qualifications, the authorized bodies that conduct the exam and issue the license for certified auditor, the amount of the price, the number of exams, the number of auditing companies and certified auditors and so on.

The information is taken from the websites of:

- Institute of Certified Auditors of the Republic of Macedonia; [3]

- Chamber of Certified Auditors of the Republic of Serbia; [4]

- State Audit Institution of the Republic of Serbia; [5] 
- Institute of Chartered Accountants and Auditors of Montenegro; [6]

- Authorized Audit Authority - Montenegro [7]

- Slovenian Institute of Auditors; [8]

- Chamber of Audit - Bosnia and Herzegovina [9]

- Association of Accountants, Auditors and Financial Professionals of Bosnia and Herzegovina

\subsection{Required qualifications}

Table 1: Necessary degree of education

\begin{tabular}{|c|c|c|c|c|c|}
\hline & Macedonia & Serbia & Montenegro & $\begin{array}{l}\text { Bosnia and } \\
\text { Herzegovina }\end{array}$ & Slovenia \\
\hline $\begin{array}{l}\text { Previous } \\
\text { education }\end{array}$ & $\begin{array}{l}\text { Bachelor } \\
\text { Degrees with } 240 \\
\text { ECTS in the field } \\
\text { of economics }\end{array}$ & $\begin{array}{l}\text { Bachelor } \\
\text { Degrees with } \\
240 \text { ECTS in } \\
\text { the field of } \\
\text { economics }\end{array}$ & $\begin{array}{l}\text { Bachelor } \\
\text { Degrees with } \\
240 \text { ECTS in } \\
\text { the field of } \\
\text { economics }\end{array}$ & $\begin{array}{l}\text { Bachelor } \\
\text { Degrees with } \\
240 \text { ECTS from } \\
\text { any area }\end{array}$ & $\begin{array}{l}\text { Bachelor } \\
\text { Degrees } \\
\text { with } 240 \\
\text { ECTS in the } \\
\text { field of } \\
\text { economics }\end{array}$ \\
\hline
\end{tabular}

The same conditions in which the beginnings of the audit in the Balkans are born, allude to the fact that the manner and protocol in which the audit will begin and be conducted will be similar or identical. The complexity and the great responsibility that the audit brings as a process, put the focus on the persons (auditors) who will implement it, ie on their qualifications and the necessary education. Namely, higher education in the field of economics is required as a previous education (diploma with completed four-year higher education or diploma with 240 credits according to the European Credit Transfer System (ECTS). But in Bosnia and Herzegovina a recognized title can be obtained by a graduate at EVERY college, so it does not matter if the person is a lawyer, pharmacist, political scientist, veterinarian, etc. The basic requirement is (learning) and taking the aforementioned exams, as well as the aforementioned experience.

\subsection{Authority which administers the exam}

Table 2: Institution authorized to conduct the exam

\begin{tabular}{l|l|l|l|l|l|} 
& Macedonia & Serbia & Montenegro & $\begin{array}{l}\text { Bosnia and } \\
\text { Herzegovina }\end{array}$ & Slovenia \\
\hline $\begin{array}{l}\text { Institution } \\
\text { authorized to } \\
\text { conduct the } \\
\text { exam }\end{array}$ & $\begin{array}{l}\text { Institute of } \\
\text { certified } \\
\text { auditors }\end{array}$ & $\begin{array}{l}\text { Chambers } \\
\text { of auditor }\end{array}$ & $\begin{array}{l}\text { Ministry of } \\
\text { Finance }\end{array}$ & $\begin{array}{l}\text { Federation of } \\
\text { Accountants, Auditors } \\
\text { and Financial Workers }\end{array}$ & $\begin{array}{l}\text { Institute of } \\
\text { auditors }\end{array}$ \\
\hline
\end{tabular}


The next step in obtaining an auditing license is to take the exam. From the previous analysis we can conclude that in different countries different qualifications are needed to be able to start taking the professional exams, and at the same time the difference in the body that conducts the exam is perceived. The body conducting the exam should be managed by experts in the field of auditing.

Relevant authorities publish an announcement or a call (depending on the country) for candidates to take exams and obtain the title of auditor. In Macedonia, Serbia, Slovenia and Bosnia and Herzegovina, the exam is conducted by an organized body called a chamber, institute or federation, while in Montenegro the body in charge of such exams is the Ministry of Finance. Montenegro is the only Balkan country that differs on this issue.

\subsection{Authority issuing the license}

Table 3: The institution that issue a licence

\begin{tabular}{l|l|l|l|l|l|} 
& Macedonia & Serbia & Montenegro & $\begin{array}{l}\text { Bosnia and } \\
\text { Herzegovina }\end{array}$ & \\
\hline $\begin{array}{l}\text { The } \\
\text { institution } \\
\text { that issue a } \\
\text { licence }\end{array}$ & $\begin{array}{l}\text { Council for } \\
\text { Audit Promotion } \\
\text { and } \\
\text { Development }\end{array}$ & $\begin{array}{l}\text { Chambers } \\
\text { of auditor }\end{array}$ & $\begin{array}{l}\text { Ministry of } \\
\text { Finance }\end{array}$ & $\begin{array}{l}\text { Federal Ministry } \\
\text { of Finance }\end{array}$ & $\begin{array}{l}\text { Institute of } \\
\text { auditors }\end{array}$ \\
\hline
\end{tabular}

In each country, a different authorized body conducts the examination for obtaining the title of certified auditor and issues a license for certified auditor.

In Macedonia, the Council for Audit Promotion and Development has this authority. The Council as a authorized body, independent and supervisied by public powers determined by the Law on Audit (Official Gazette 158/10). .[10]

In Serbia, the license is issued by the Chamber of Certified Auditors, established by the Law on Accounting and Auditing (Official Gazette of RS, No. 46/2006), to promote and develop the accounting and auditing profession.

The model established by the Chamber of Certified Auditors is based on the experience and solutions of the chambers and institutes in this area of most Western European countries and almost all countries that have recently joined the EU.

In Montenegro, almost all activities are coordinated and implemented by the Ministry of Finance. While in other countries there is a special body under the supervision of the Ministry of Finance, which conducts the exam and issues the license for certified auditor.

In Bosnia and Herzegovina, the authorization to issue a license is held by the Federal Ministry of Finance and it is regulated by law, namely Article 56 and Article 57 of the Law on Accounting and Auditing. [11]

In Slovenia, too, the Institute for Certified Auditors has such competence. This authorized body is a non-profit professional organization, established in September 1993 on the basis of the Law on Audit (coordinated under the EU Directive). The Institute is a member of major professional international organizations, such as in the field of accounting, the International 
Federation of Accountants (IFAK), in the field of auditing of the Federation of Auditors (Accounting Europe) and in the field of valuation, which further strengthens its role in implementing audit and justifies its authorization.

\subsection{Number of exams}

Table 4: Number of exams

\begin{tabular}{|c|c|c|c|c|c|}
\hline & Macedonia & Serbia & Montenegro & $\begin{array}{l}\text { Bosnia and } \\
\text { Herzegovina }\end{array}$ & Slovenia \\
\hline $\begin{array}{l}\text { Number of } \\
\text { exams }\end{array}$ & $\begin{array}{l}2 \text { levels } \\
\text { I level - } 4 \\
\text { II level - } 4 \\
\text { Total } 8\end{array}$ & $\begin{array}{l}2 \text { levels } \\
\text { I level - } 7 \\
\text { II level - } 6 \\
\text { Total } 13\end{array}$ & 9 exams & 5 exams & $\begin{array}{l}2 \text { levels } \\
\text { I level -12 } \\
\text { exams } \\
\text { II level - } \\
\text { case study }\end{array}$ \\
\hline
\end{tabular}

The number of exams also varies from country to country. The number of exams varies from a minimum of 5 exams in Bosnia and Herzegovina to a maximum of 12 exams in Slovenia. In some countries there is an examination program that is not gradated, such as Montenegro and Bosnia and Herzegovina.

In other countries, such as Macedonia, Serbia and Slovenia, the overall program consisting of exam topics and subjects is divided into levels. These are usually two levels that can consist of an equal number of exams, as is the case in Macedonia or where the number of exams varies from level to level as in Serbia.

In Slovenia there is also a hierarchical division of exam levels, but here it is a level that covers theoretical exams and a second level that contains a practical part. Such a practical part of the exam exists only in Slovenia from the analyzed countries.

\subsection{Price}

Table 5: Exam costs

\begin{tabular}{|c|c|c|c|c|c|}
\hline & Macedonia & Serbia & Montenegro & $\begin{array}{l}\text { Bosnia and } \\
\text { Herzegovina }\end{array}$ & Slovenia \\
\hline Price & $150 \underline{€ / \text { per exam }}$ & 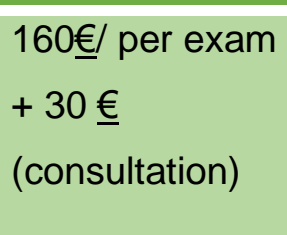 & Total $2000 \underline{€}$ & $\begin{array}{l}102.33 \underline{€} / \mathrm{per} \\
\text { exam }\end{array}$ & Total $3305 \underline{€}$ \\
\hline Total & $1200 €$ & $2080 €$ & & $511.65 \underline{€}$ & \\
\hline
\end{tabular}


Price plays a major role, especially in countries in transition. Comparative data show prices in the Balkan countries analyzed and what they include. Price is often associated with the standard of living of a given country, but also the level and interest in specialization in this area. In the later analysis and survey conducted this will be explained in more detail, but to a large extent the price is defined by the demand, living standard and opportunities and powers that are expected to be acquired. The price usually includes only the professional exams, but an interesting fact is that in Slovenia the above price includes the price for education through exams and defense of the final thesis, as well as access to materials on the closed part of the website of the Institute. Although it seems that the price for the exams in Slovenia is the highest, with more detailed analysis we can conclude the opposite, because that price includes all the accompanying costs for one candidate.

\subsection{Number of registered auditors and audit firms}

Table 6: Number of registered auditors and audit companies

\begin{tabular}{|c|c|c|c|c|c|}
\hline & Macedonia & Serbia & Montenegro & $\begin{array}{l}\text { Bosnia and } \\
\text { Herzegovina }\end{array}$ & Slovenia \\
\hline $\begin{array}{l}\text { Number of } \\
\text { registered } \\
\text { auditors } \\
\text { and auditi } \\
\text { companies }\end{array}$ & $\begin{array}{l}26 \text { - companies } \\
9 \text { - sole } \\
\text { proprietors } \\
\text { - } 211 \text { certified } \\
\text { auditors }\end{array}$ & $\begin{array}{l}70 \text { companies } \\
313 \text { certified } \\
\text { auditors }\end{array}$ & $\begin{array}{l}86 \text { certified } \\
\text { auditors }\end{array}$ & $\begin{array}{l}365 \text { certified } \\
\text { auditors }\end{array}$ & $\begin{array}{l}189 \text { certified } \\
\text { auditors }\end{array}$ \\
\hline
\end{tabular}

All certified auditors, audit firms and certified auditor - sole proprietor are registered in an appropriate register in which records are kept of the number of persons, regardless of legal or physical. In each country, within the functioning system, there is a separate register for persons from the auditing activity. The registers are under the jurisdiction of the audit institution named as institute, chamber, federation, etc.

The number of certified auditors varies in the Balkan countries. The country with the largest number of licensed auditors is Bosnia and Herzegovina. From the previous analysis and data we can also see that the number of exams in Bosnia and Herzegovina is also the smallest, but the smallest budget is needed to obtain such a license. This more affordable price, compared to other countries, may be the reason for the greater interest in the profession of certified auditor.

Right behind Bosnia and Herzegovina, Serbia is in second place in the number of certified auditors, followed by Macedonia, Slovenia and finally Montenegro.

When it comes to Macedonia, from the prepared registers of the Institute for Certified Auditors there are relevant and available data on the number of audit companies, Certified Auditor sole proprietor and certified auditors. 


\section{ACCA}

Despite the attempts and efforts to develop the auditing profession in the Balkans, there is ACCA, the most advanced auditing Employers around the world are looking for ACCA members to run their business towards sustainable success. This is because they know that ACCA members are strategic thinkers with high ethical integrity, strong financial knowledge and proper business activity body in the world. The ASSA family has more than 500,000 members worldwide who strive to build the profession to a higher standard and to make society more equitable and transparent.[12] Employers around the world are looking for ACCA members to run their business towards sustainable success. This is because they know that ACCA members are strategic thinkers with high ethical integrity, strong financial knowledge and proper business activity.

What ACCA offers to its student members is the availability of the most up-to-date and rich literature, timely calendar notification for exam dates for certified auditor, sufficient number of exam registration sessions, professional assistance in mastering the material, students receive 24- hourly support from the ACCA Connect team, flexibility in learning and taking exams, etc.

Something that is particularly different from the possibilities in the Balkans is that the ACCA provides the opportunity to take the professional examinations for a certified auditor after completing secondary education. Specifically, all those who have completed at least secondary education have the right to take the exam, with those who start with secondary education taking 3 more exams than those who start taking the professional exams after completing higher education.

There is no time limit on how long students can take the Applied Knowledge and Skills Exams. After students pass their first Strategic Professional Exam, they have seven years to pass the remaining exams, and to obtain the required qualifications they need to have at least 3 years of work experience. The fastest way to become a member is to work and study at the same time.

\section{How many students are interested in the profession of certified auditor}

For the purposes of the audit of the Balkan countries, a survey was conducted using a survey questionnaire in the case of a number of former Yugoslav republics (Macedonia, Serbia, Montenegro, Bosnia and Herzegovina and Slovenia). The survey questionnaire was answered by students from the Faculties of Economics. Students from these countries expressed their views on auditing and the auditing profession as a whole. Number of surveyed students in the form of country about 100 .

Recognized the views and opinions on the audit through responsibility from the survey questionnaire which consists of 10 questions. The survey was conducted in two forms, physical and electronic, compared to the conditions and opportunities. The results obtained from the surveyed students are processed and presented as a percentage. 
Question 1. An audit is a review of the veracity and accuracy of the information presented in the financial statements

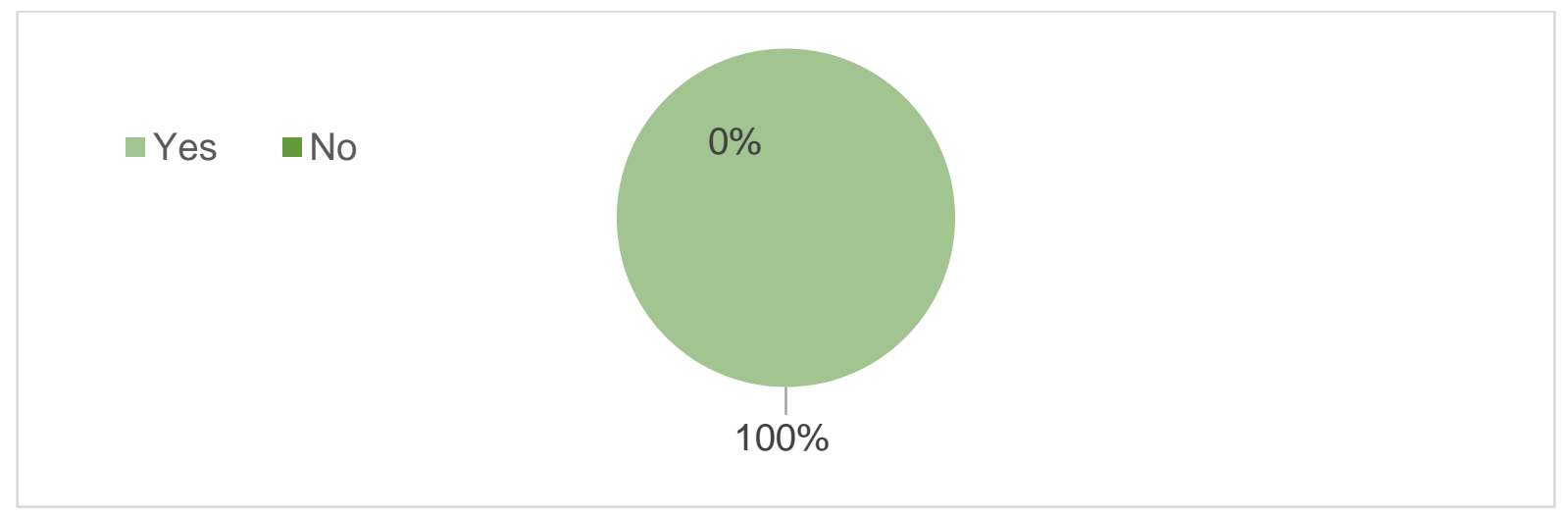

Figure 1 Distribution of respondents' answers to question 1

The answer to the first question of all students is "Yes", which lets us know that all students are sufficiently informed and familiar with the activity covered by the audit.

The result of $100 \%$ does not indicate that the students from the Faculties of Economics who are not in the field of Accounting and Auditing have knowledge of the subject of audit work.

Question 2. The audit shall increase the credibility of the information presented in the financial statements

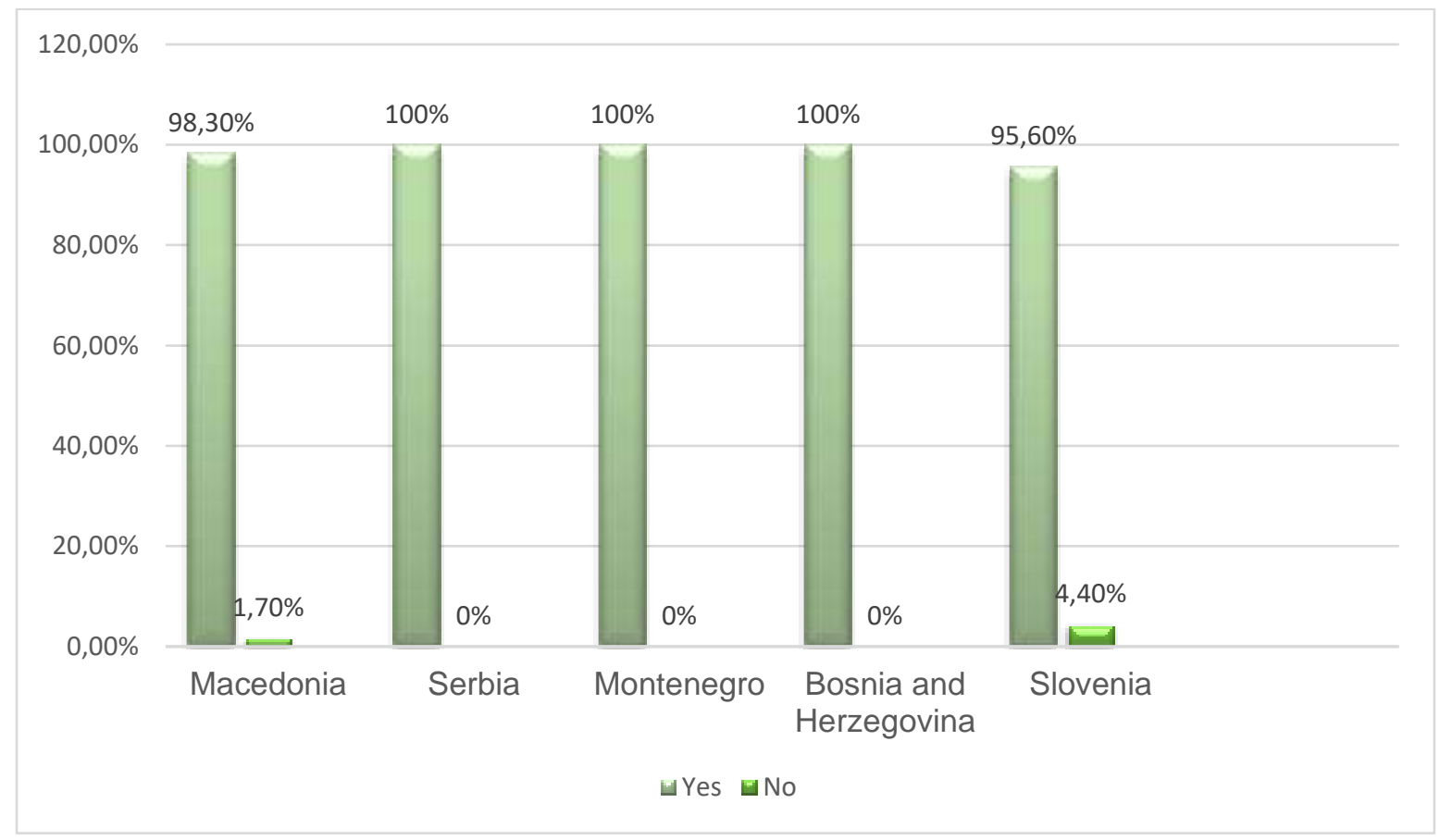

Figure 2 Distribution of respondents' answers to question 2 
In Macedonia, the majority of respondents gave a affirmative answer "YES", and only $1.70 \%$ answered "NO", unlike the respondents from Bosnia and Herzegovina, Montenegro and Serbia, who gave a full (100\%) affirmative answer.

While in Slovenia $95.6 \%$ gave a positive answer, and $4.4 \%$ negative. Given the previous analyzes of the authorities and the level of implementation of education, such results are surprising.

Question 3. Are you aware that after graduating from the Faculty of Economics, you can take exams to obtain the title of certified auditor?

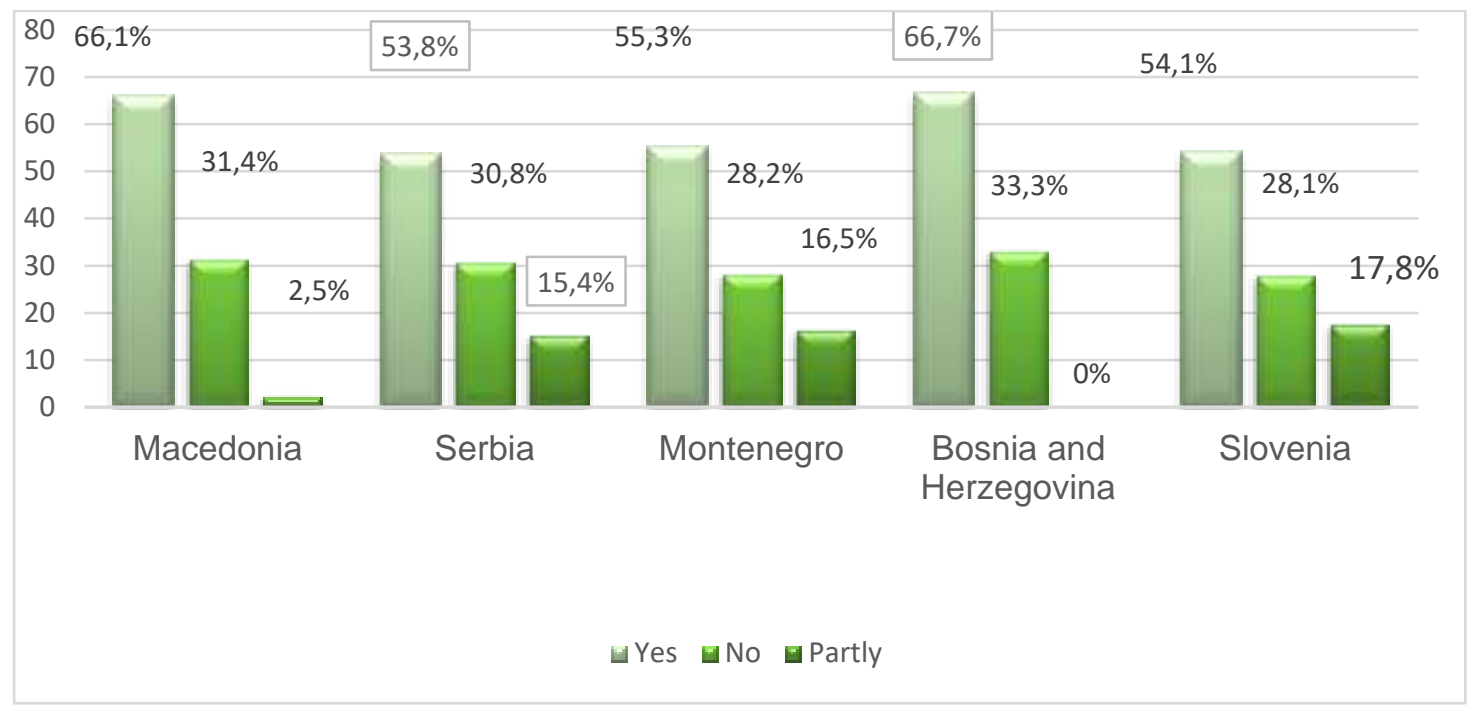

Figure 3 Distribution of respondents' answers to question 3

Regarding the fact that students are aware that after completing their undergraduate studies they can start taking the exams for obtaining a license for certified auditor, over $53 \%$ of students are generally aware. This information is most accessible for students in Macedonia and Bosnia and Herzegovina where over $66 \%$ of students are informed about their opportunities after completing the first cycle of studies. 
Question 4. Do you know what conditions you need to meet to get a certified auditor license?

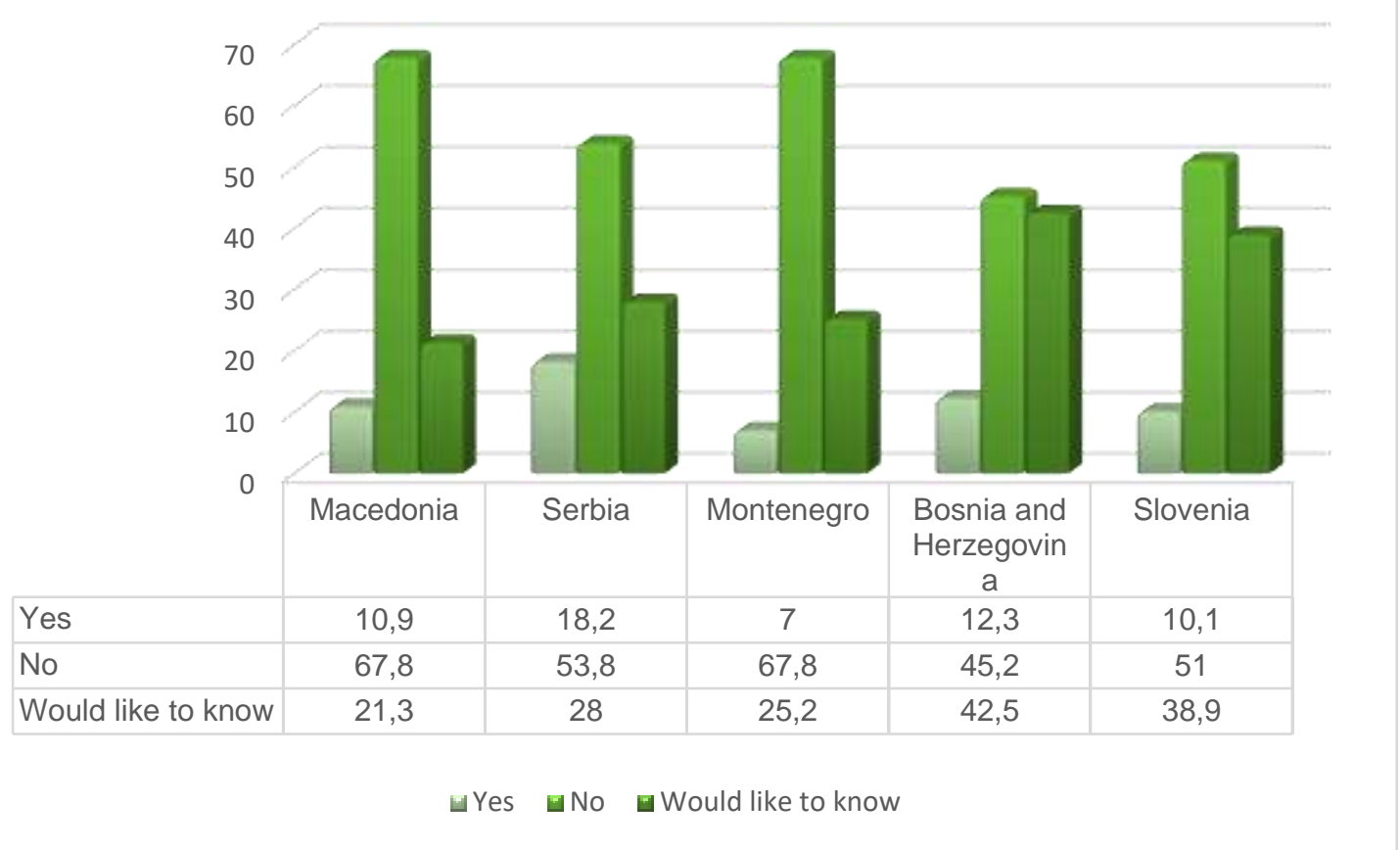

Figure 4 Distribution of respondents' answers to question 4

Leading percentage parameters for knowing the conditions for obtaining a license belong to Macedonia and Montenegro with $67.8 \%$, followed by Serbia $53.8 \%$, Slovenia $51 \%$ and the least knowledge of the conditions is in Bosnia and Herzegovina. But despite these percentage parameters, the interest in knowing the conditions is highest in Bosnia and Herzegovina, and lowest in Macedonia.

The number of respondents who answered "NO" is $0-20 \%$, ie they do not know the conditions for obtaining a license.

Question 5. Are you familiar with obtaining a licensed auditor license from the London-based International Association of Chartered Auditors (ACCA)?

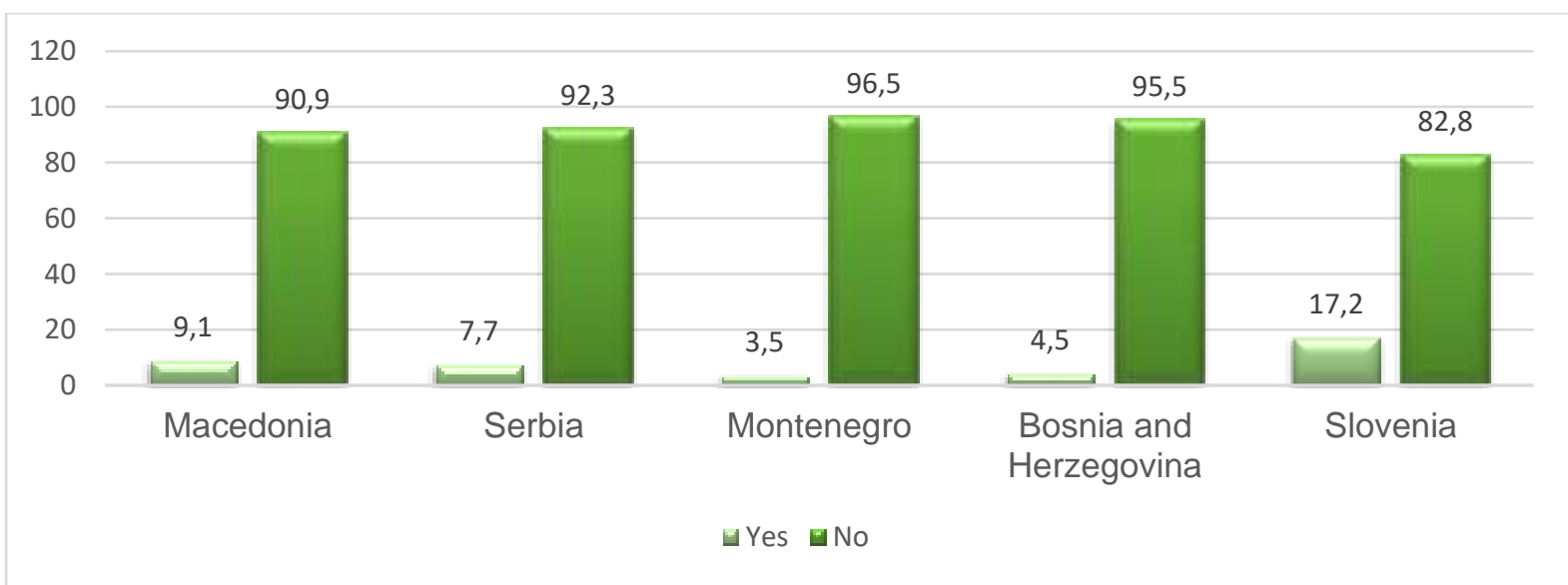

Figure 5 Distribution of respondents' answers to question 5

When it comes to the International Association of Certified Auditors, we have found that very few students in the countries where the survey was conducted are aware of this possibility. In almost all countries over $90 \%$ of respondents are not at all aware of how to obtain a certified auditor license through the ASSA. The largest number of informed students according to the 
percentage indicators is in Slovenia, but still the information there is at a very low level, only $17.2 \%$.

Question 6. Do you think that you should be given the opportunity to take the title of auditor after finishing high school?

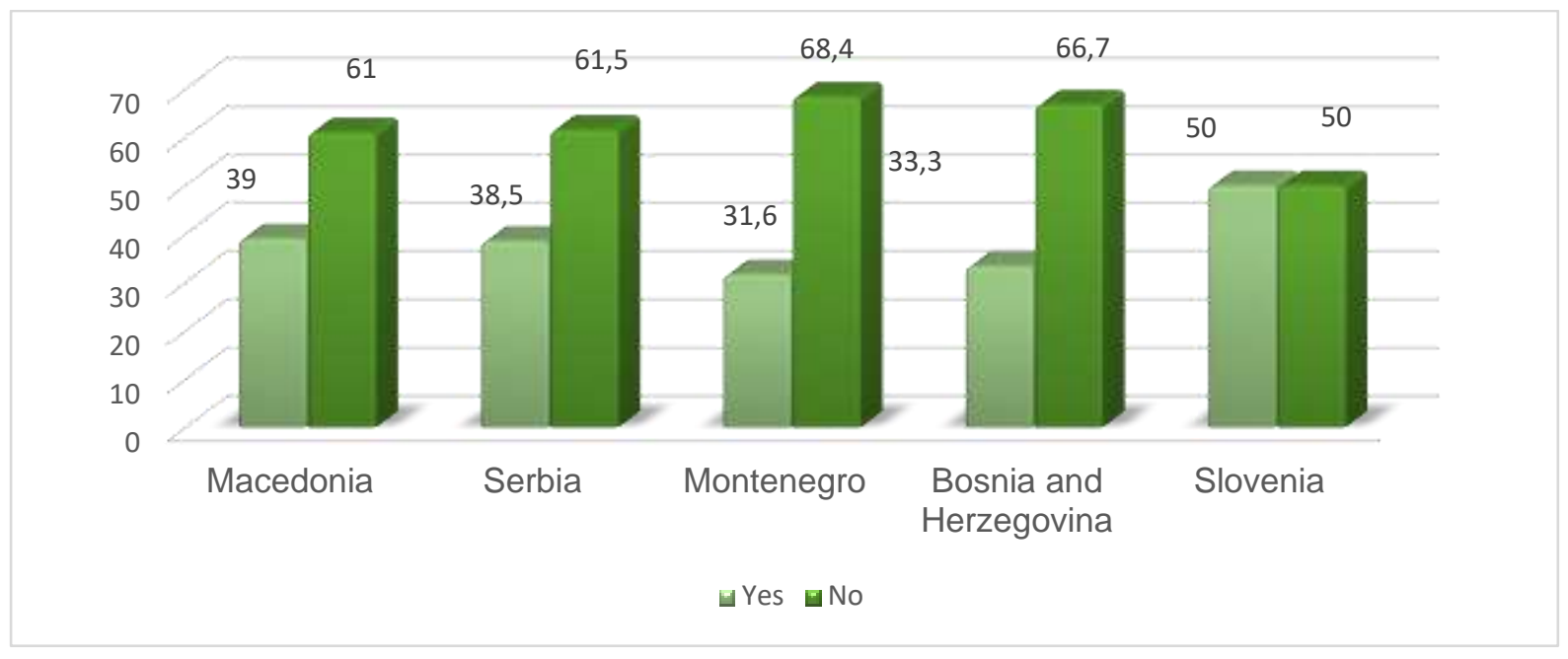

Figure 6 Distribution of respondents' answers to question 6

The highest percentage of the answers of the respondents are positive, the percentage is: Montenegro 68.4\%, Bosnia and Herzegovina 66.7\%, Serbia $61.5 \%$, Macedonia $61 \%$ where there is interest in having the opportunity to take the exams after high school. In Slovenia, opinions are divided (50\%-50\%) despite European standards and dual education, most of the respondents who answered "NO" to the possibility of taking exams to obtain the title of auditor after graduating from high school, are from Slovenia.

Question 7. How familiar are you with the auditor's job responsibilities?

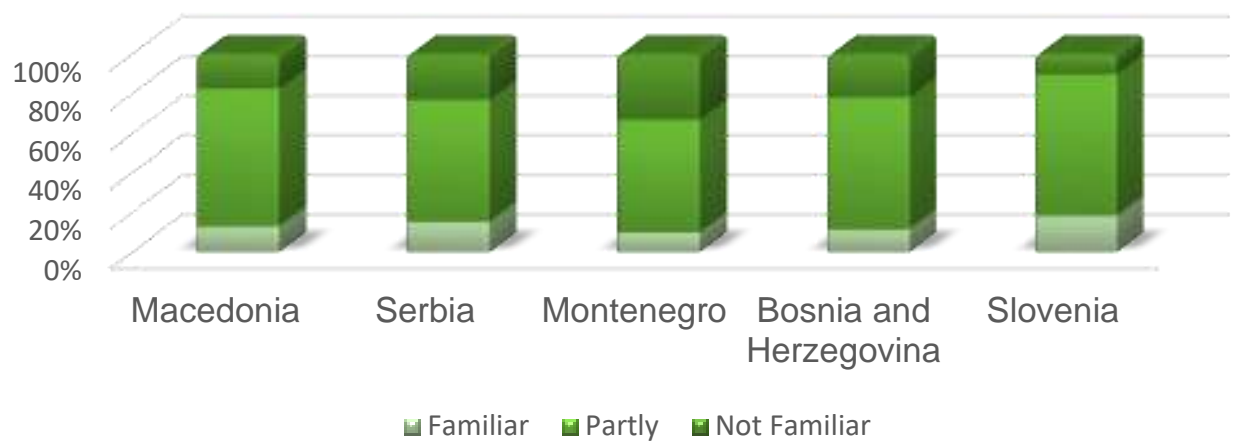

Figure 7 Distribution of respondents' answers to question 7 
Table 7 Percentage review of responses

\begin{tabular}{|c|c|c|c|}
\hline & Familiar & Partly & Not Familiar \\
\hline Macedonia & $13 \%$ & $\begin{array}{l}69,6 \\
\%\end{array}$ & $17,4 \%$ \\
\hline Serbia & $15,4 \%$ & $\begin{array}{l}61,5 \\
\%\end{array}$ & $23,1 \%$ \\
\hline Montenegro & $10 \%$ & $\begin{array}{l}56,8 \\
\%\end{array}$ & $33,2 \%$ \\
\hline $\begin{array}{l}\text { Bosnia and } \\
\text { Herzegovina }\end{array}$ & $11,5 \%$ & $\begin{array}{l}66,7 \\
\%\end{array}$ & $21,8 \%$ \\
\hline Slovenia & $18,4 \%$ & $\begin{array}{l}71,5 \\
\%\end{array}$ & $10,1 \%$ \\
\hline
\end{tabular}

The chronological movement from the least knowledgeable about the auditor to the most knowledgeable students starts in Serbia. In this country, as many as $33.1 \%$ of the respondents are not at all familiar with the scope of work of an auditor. Most of the students in all countries answered that they are partially familiar with the work of the auditor, and the most informed and most interested in the audit work are the respondents from Slovenia.

Question 8. In your opinion, why is the interest in the auditing profession with lower growth compared to other economic disciplines?

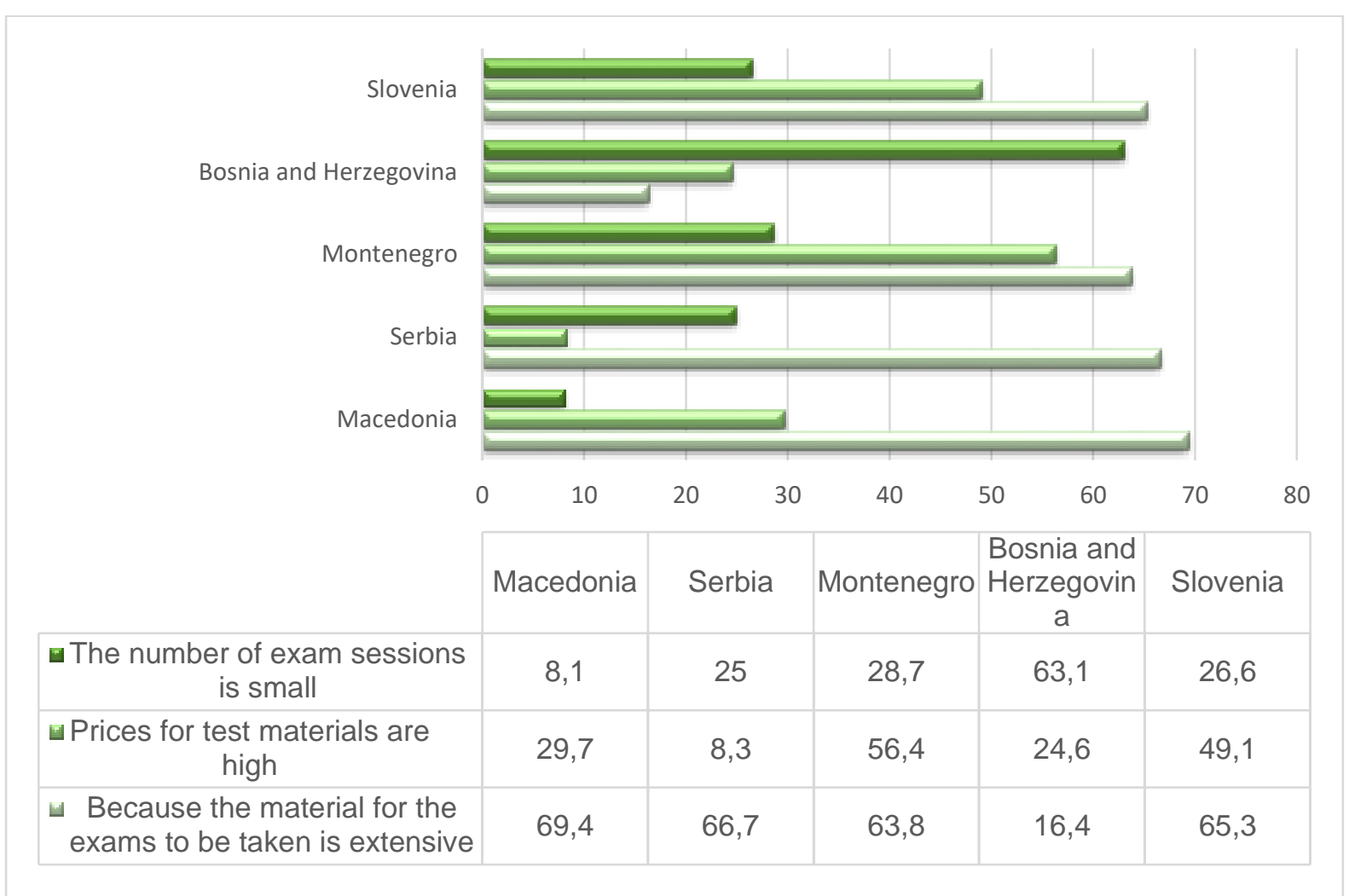

Figure 8 Distribution of respondents' answers to question 8 
One of the inevitable questions was exactly this: Why the interest of the auditing profession is growing less than other economic disciplines, and the results were as follows:

The offered answers were:

- Small number of exam sessions;

- High prices for materials;

- Extensive subject matter.

The highest percentage in most countries (except Bosnia and Herzegovina) belonged to the extensive exam material as the main culprit for the weaker growth of auditing compared to other economic disciplines, namely Macedonia (69.4\%), Serbia (66.7\%), Slovenia (65.3\%), Montenegro (63.8\%). In contrast, the largest percentage in Bosnia and Herzegovina (63.1\%) belonged to the small number of exam sessions.

Price as a factor was found in the third, last place among the reasons for weaker growth of auditing compared to other economic disciplines. It is the biggest obstacle in Montenegro, where $56.4 \%$ of respondents said that prices are high, followed by Slovenia with $49.1 \%$.

Question 9. Would you choose auditing as your life profession?

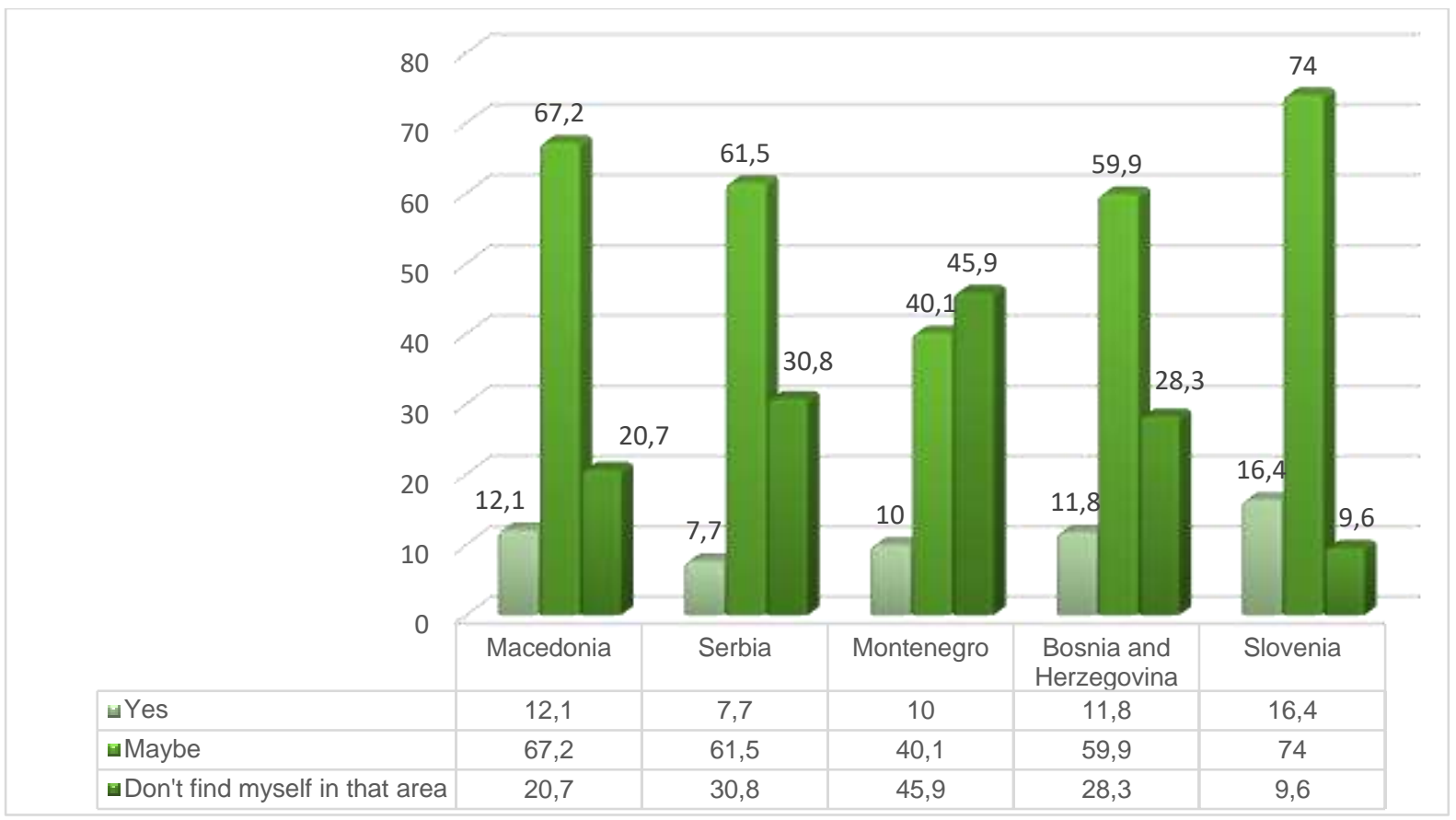

Figure 9 Distribution of respondents' answers to question 9

In general, in most countries a fairly small percentage of respondents would opt for the auditing profession as their dream job. From $7.7 \%$ in Serbia to $16.4 \%$ in Slovenia, students are confident in their decision to be auditors. Perhaps this is due to the lack of information about the scope of work of the auditor as we noted from the previous survey question, where students were partially acquainted with the work responsibilities of the auditor. This may be the reason why most students answered the question "Maybe" and are not sure if they would swim in the audit waters. The Macedonian students are the most hesitant, as many as $67.2 \%$ of them do not rule out the possibility to choose auditing as their life profession. Montenegrin students, on the other hand, $45.9 \%$ are the least found in this area. 
Question 10. What would motivate you to become a certified auditor?

\begin{tabular}{|c|c|c|c|c|c|c|}
\hline \multirow{7}{*}{$\begin{array}{r}\text { Slovenia } \\
\text { Bosnia and Herzegovina } \\
\text { Montenegro } \\
\text { Serbia } \\
\text { Macedonia }\end{array}$} & \multicolumn{6}{|c|}{ 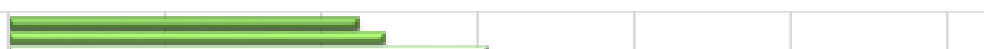 } \\
\hline & \multicolumn{6}{|c|}{ 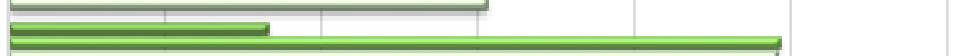 } \\
\hline & \multicolumn{6}{|c|}{ 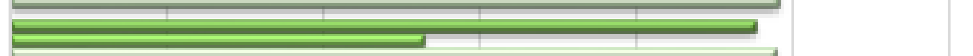 } \\
\hline & \multicolumn{4}{|c|}{ 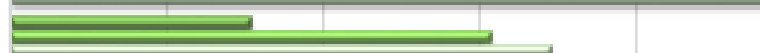 } & & \\
\hline & \multicolumn{6}{|c|}{ 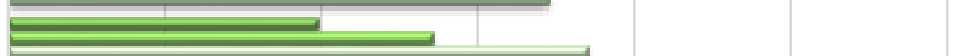 } \\
\hline & \multicolumn{6}{|c|}{100} \\
\hline & Macedonia & Serbia & Montenegro & $\begin{array}{c}\text { Bosnia and } \\
\text { Herzegovin } \\
\text { a }\end{array}$ & Slovenia & \\
\hline $\begin{array}{l}\text { Improving the quality of } \\
\text { financial statements }\end{array}$ & 39,7 & 30,8 & 95,3 & 33,3 & 44,7 & \\
\hline $\begin{array}{c}\text { Dontinuous professional } \\
\text { development }\end{array}$ & 54,3 & 61,5 & 52,9 & 98,7 & 48,1 & \\
\hline 甲 High salary & 74,1 & 69,2 & 98 & 98,3 & 61,2 & \\
\hline \multicolumn{7}{|c|}{ Improving the quality of financial statements } \\
\hline \multicolumn{7}{|c|}{ Continuous professional development } \\
\hline \multicolumn{7}{|c|}{$\square$ High salary } \\
\hline
\end{tabular}

Figure 10 Distribution of respondents' answers to question 10

\subsection{Conclusions after the survey questionnaire}

From the conducted survey we came to the conclusions that:

1. Students have a basic knowledge of the existence of auditing.

2. They are not sufficiently informed about the ways to obtain a license for certified auditor.

3. They are not at all familiar with the international audit organizations, ways to obtain international licenses to perform audit services, etc.

4. Only partially have knowledge of the auditor's work responsibilities

5. Very few students would choose auditing as their life calling because the subject matter to be studied is extensive and salaries are not at a satisfactory level.

\section{Conclusion}

The audit was practiced within the former SFRY through the Social Accounting Service, but due to the chosen way of institutionalization and implementation in practice it did not give the desired results and could not be called an independent audit profession. In each of the analyzed countries after the break-up of the former Yugoslavia, an appropriate legal and institutional framework was adopted which prescribed and institutionalized the functioning of the audit profession. In almost all countries (except Montenegro) the exam for obtaining the title of certified auditor is organized by a professional association (institute, chamber, association) that takes care of the functioning and dignity of the audit profession.

In order to attract interest among young people to choose the profession of auditor for their lifelong challenge, efforts should be made to simplify the procedure for taking exams for 
certified auditor in terms of: defined accessible literature, reducing the cost of taking exams, increasing the number of sessions during the year, precisely determined dates for taking each exam within each session (at least one year earlier), giving the opportunity to take and candidates with completed secondary education (of course with additional exams) such as the criteria for obtaining the title of certified auditor at the International Association of Chartered Accountants.

\section{References:}

1. Nikolovski PhD. Pece, Organization of the Audit of Financial Statements, Faculty of Economics, Prilep, 2004, p.44

2. Stanoevski PhD .Stanoe, Control and Audit, Faculty of Economics - Skopje, 1998, p. 351-358.

3. http://www.iorrm.org.mk/

4. https://www.kor.rs/

5. https://www.dri.rs/\%D0\%BD\%D0\%B0\%D1\%81\%D0\%BB\%D0\%BE\%D0\%B2\%D0\%B D\%D0\%B0.1.html

6. http://www.irrcg.co.me/

7. https://www.revizorskotijelo.me/

8. https://si-revizija.si/o-institutu/slovenski-institut-za-revizijo

9. https://www.rkfBosnia and Herzegovina.ba/

10. Dimitrova, PhD. Janka "Audit - theoretical and practical aspects", University Goce Delchev - Stip, 2020 p.63

11. Law on Accounting and Auditing in the Federation of Bosnia and Herzegovina ("Official Gazette of the Federation of Bosnia and Herzegovina", No. 83/09).

12. https://www.accaglobal.com/gb/en.html 